\title{
Comparison of three methods of DNA extraction from human bones with different degrees of degradation
}

\author{
Joanna Jakubowska • Agnieszka Maciejewska • \\ Ryszard Pawłowski
}

Received: 15 February 2011 / Accepted: 16 June 2011 / Published online: 30 June 2011

(C) The Author(s) 2011. This article is published with open access at Springerlink.com

\begin{abstract}
There is a necessity for deceased identification as a result of many accidents and sometimes bones are the only accessible source of DNA. So far, a universal method that allows for extraction of DNA from materials at different stages of degradation does not exist. The aims of this study were: the comparison of three methods of DNA extraction from bones with different degree of degradation and an evaluation of the usefulness of these methods in forensic genetics. The efficiency of DNA extraction, the degree of extract contamination by polymerase chain reaction (PCR) inhibitors and the possibility of determining the STR loci profile were especially being compared. Nuclear DNA from bones at different states of degradation was isolated using three methods: classical, organic phenolchloroform extraction, DNA extraction from crystal aggregates and extraction by total demineralisation. Total demineralisation is the best method for most cases of DNA extraction
\end{abstract}

Electronic supplementary material The online version of this article (doi:10.1007/s00414-011-0590-5) contains supplementary material, which is available to authorized users.

J. Jakubowska

Intercollegiate Faculty of Biotechnology of University of Gdańsk and Medical University of Gdańsk,

Kładki 24,

80-822 Gdańsk, Poland

J. Jakubowska $\cdot$ A. Maciejewska $\cdot$ R. Pawłowski

Institute of Forensic Medicine,

Medical University of Gdańsk,

Dębowa 24,

80-204 Gdańsk, Poland

R. Pawłowski ( $\square)$

Institute of Forensic Research,

Westerplatte 9,

31-033 Kraków, Poland

e-mail: richard@gumed.edu.pl from bones, although it does not provide pure DNA. DNA extraction from aggregates removes inhibitors much better and is also a good method of choice when identity determination of exhumed remains is necessary. In the case of not buried bones (remains found outside) total demineralisation or phenol-chloroform protocols are more efficient for successful DNA extraction.

Keywords Bones · DNA extraction · Crystal aggregates . Total demineralisation $\cdot$ Real-Time PCR $\cdot$ Inhibition

\section{Introduction}

There is a necessity for identification of deceased individuals as a result of many accidents, like mass disasters, war crimes, murders with hiding and defragmentation of a body, traffic accidents, terrorist attacks when the identity of the victims is unknown or when remains of well-known people are identified. Sometimes, bones are the only accessible source of DNA, thanks to their structure, which preserves DNA comparatively well and for a long time. The main problems of DNA extraction from bones are DNA degradation due to environmental factors and the presence of soil-derived inhibitors like humus acids [1-10]. So far, a universal method that allows for extraction of DNA from materials at different stages of degradation giving inhibitor-free DNA samples has not been reported, and new methods are still being searched for and improved. One of the recently described new methods is DNA extraction from aggregates (EA) [11], which assumes extraction of DNA that is fixed in aggregates of bone crystals [11, 12]. The aim of our study was to evaluate this new method and to compare it with classic phenol-chloroform bone DNA extraction (PCE) [13] and the method of total demineralisation (TD) [14]. 


\section{Materials and methods}

Bones

Nine long bones marked B1-B9 with different histories and degrees of degradation were used. The history of the bones was as follows: B1 is a 10-year-old bone of a male exhumed from soil; B2 is a 3-month-old bone of a female found outside in winter (March); B3 is a 2-month-old bone of a male found outside in summer (June); B4 is a 3-month-old bone of a male found inside in summer (July); B5 is a 62-year-old bone of a male exhumed from sand; B6 is a 1-month-old bone of a male found outside; B7 is a few-day-old bone of a male found outside in winter (March); B8 is ta male bone obtained just after death (car accident); and B9 is an 8-year-old bone of a male exhumed from soil. The indicated age of bones is time from death to corpse disclosure. After an autopsy and the bone extraction, the bones were kept at $-80^{\circ} \mathrm{C}$ until the genetic analysis. Remains of soft tissue, blood or other bone fragments were used as comparative material.

\section{Bone preparation}

All bones were mechanically cleaned, dried, washed, exposed to $\mathrm{NaOCl} 10 \%$ for a few minutes and washed again, milled $(6 \times 90$ s cycles $)$ in liquid nitrogen using cryogenic mill (6850 Freezer Mill Spex CertiPrep, USA). Every bone was prepared separately using sterile, disposable tools in a specially designed room.

\section{DNA extraction}

DNA was extracted from whole bone powder using the classical phenol-chloroform method (PCE) in accordance with the modified protocol described by Hochmeister and Budowle [13]. Briefly, bone powder was digested overnight, and DNA was extracted with phenol-chloroform-isoamyl alcohol, purified and concentrated on microcolumns (Ultracel YM 100, Microcon) to $15 \mu \mathrm{l}$.

DNA was extracted from aggregates of bone crystals (EA) as described by Salamon et al. [11]. In brief, $500 \mathrm{mg}$ of bone powder was incubated with $2.5 \% \mathrm{NaOCl}$ for $4 \mathrm{~h}$. The pellet was washed with water and 95\% ethanol, resuspended in absolute ethanol, centrifuged and dried overnight. The dried material was sonicated in $95 \%$ ethanol, vortexed and allowed to settle. The precipitant was washed with $2.5 \% \mathrm{NaOCl}$ and water and exposed to decalcification in $0.5 \mathrm{M}$ EDTA $\mathrm{pH} 8.0$, with a few exchanges of EDTA solution followed by centrifugation. Decalcified bone powder was incubated with proteinase $\mathrm{K}$, DTT, EDTA, $\mathrm{NaCl}$ and $\mathrm{SDS}$ for $30 \mathrm{~min}$ at $60^{\circ} \mathrm{C}$ and then overnight at $37^{\circ} \mathrm{C}$. DNA was extracted with phenolchloroform-isoamyl alcohol, purified and concentrated by ultrafiltration (Ultracel YM 100, Microcon) to $15 \mu \mathrm{l}$.

DNA was extracted by the total demineralisation technique (TD) in accordance with the protocol described by Loreille et al. [14]. Briefly, $500 \mathrm{mg}$ of bone powder was incubated overnight at $56^{\circ} \mathrm{C}$ in the extraction buffer $(0.5 \mathrm{M}$ EDTA, $1 \%$ lauryl sarcosyl) and $200 \mathrm{ml}$ of $20 \mathrm{mg} / \mathrm{ml}$ proteinase $\mathrm{K}$, then concentrated using Centricon Plus-20 and purified with Centricon 30 centrifugal filter unit (Millipore).

During all steps of extraction, appropriate controls and decontamination processes were followed.

\section{DNA recovery and PCR inhibition}

Recovery of DNA and degree of extract contamination by polymerase chain reaction (PCR) inhibitors were evaluated using Real-Time PCR with Quantifiler Human kit (Applied Biosystems, USA) in accordance with the manufacturer's protocol. If a threshold had been surpassed by IPC curve later than in the 29th cycle ( $C_{\mathrm{t}}$ of standard dilutions) or never at all, partial or full inhibition could have occurred. Total numbers of $50 \mathrm{EA}, 30 \mathrm{PCE}$, and nine TD extracts were assayed.

DNA quality

DNA quality was estimated using commercial DNA kits. Two PCR multiplex systems AmpFlSTR ${ }^{\circledR}$ SGM Plus (Applied Biosystems) and/or PowerPlex ${ }^{\circledR}$ ESX 17 (Promega) were used, as recommended by the manufacturers. Detection of PCR products using capillary electrophoresis was carried out using an ABI Prism 3130 Genetic Analyzer.

\section{Effect of decalcification time on extraction efficiency} with EA method

We used $500 \mathrm{mg}$ of bone powder (B2, B5 and B7). Extraction was performed as previously described, using the EA protocol and decalcification, which lasted 1, 3 or 5 days. EDTA was changed twice every day. Three-day decalcification experiment was performed in two repeats.

\section{Results and discussion}

The main aim of our work was to ascertain which of the three analysed methods gives better results when DNA is extracted from bones at different stages of decomposition. We chose relatively fresh bones taken from corpses and kept at $-80^{\circ} \mathrm{C}$ for a few years, and older bones excavated after a few to 62 years from soil ground. 
Table 1 DNA recovery from $500 \mathrm{mg}$ of bone powder for nine bones using EA, PCE and TD protocols

\begin{tabular}{lccc}
\hline \multirow{2}{*}{ Bone } & \multicolumn{3}{c}{$\begin{array}{l}\text { Recovery of DNA from } \\
500 \mathrm{mg} \text { of bone powder (ng) }\end{array}$} \\
\cline { 2 - 4 } & PCE & EA & TD \\
\hline $1^{\mathrm{a}}$ & 0.01 & 0.9 & 13.3 \\
2 & $10,702.5$ & 15.45 & $8,183.3$ \\
3 & 0.9 & 0.23 & 45 \\
4 & 1.35 & 1.05 & 23.3 \\
$5^{\mathrm{a}}$ & 0.3 & 2.1 & 0 \\
6 & 7.05 & 0.75 & 8.3 \\
7 & $5,326.8$ & 45.75 & $23,833.3$ \\
8 & $9,189.9$ & 115.05 & $102,114.2$ \\
$9^{\mathrm{a}}$ & 0 & 17.4 & 116.6 \\
NC & 0 & 0.002 & 0 \\
Average for exhumed bones & 0.103 & 6.53 & 43.3 \\
Average for all bones & $2,803.2$ & 21.99 & $14,926.37$ \\
\hline
\end{tabular}

Every result of EA and PCE extraction is an average of two extraction repeats

${ }^{\text {a }}$ Bones exhumed from ground, $N C$ negative control (an empty vein treated as bone powder)

\section{Efficiency and inhibition}

Efficiency of methods was determined on the basis of DNA recovery measured by Real-Time PCR assay. The obtained $R^{2}$ value for all reactions was at least 0.99 . The average amount of DNA isolated from analysed bones with TD, PCE and EA methods was 14,926, 2803 and $22 \mathrm{ng}$, respectively, per $500 \mathrm{mg}$ of bone powder (Table 1). The TD method gave remarkably better average DNA yields than PCE and EA. However, it was observed that DNA extraction from aggregates of bone crystals (EA) was the most efficient method for the 62-year-old bone (B5) exhumed from the ground. With the two other methods, no DNA was extracted (TD method) or a significantly lower amount (PCE method) was obtained. For two other exhumed relatively old bones, B1 (10 years old) and B9 ( 8 years old), the EA method gave higher DNA amounts than PCE, but the highest yields were observed for the TD method (Table 1). Obtained results suggest that, while the TD protocol gives higher recovery of DNA in general, the EA method can give better results in cases of old and severely degraded bones. Low levels of DNA obtained via the EA method for relatively fresh bones can be explained by the fact that this method isolates the DNA pool which is fixed within crystal aggregates and eliminates the rest of genetic material, contaminants, inhibitors and exogenous DNA by strong oxidant treatment $(\mathrm{NaOCl})$. In buried, more degraded bones, extra-aggregate DNA is usually severely degraded and therefore present at low levels. In contrast, for relatively fresh bones, DNA yield was considerably higher for TD and PCE than for EA method, because, due to the EA protocol, all extra-aggregate DNA was removed (see bones 2, 7 and 8, Table 1). Poor results of the organic method of DNA extraction from exhumed bones was also observed by Davoren et al. [15] when compared with the silica columns technique. Our results are similar to those described by Salamon et al. [11], who obtained about 2 orders of magnitude more DNA templates when DNA was extracted from whole bone powder (similar to PCE) as compared to DNA extracted from aggregates (EA).

Among all analysed samples, $33 \%$ of TD extracts, $17 \%$ of PCE extracts and only 4\% of EA extracts partially inhibited or could inhibit amplification. For EA extracts, only B5 could cause inhibition (only two out of ten repeats of B5 DNA extractions). No B3, B4, B5 PCE extracts and no B1, B4, B5 TD extracts allowed for proper IPC template

Table 2 Possible reasons of inhibition

\begin{tabular}{llllll}
\hline Bone & Extraction method & IPC amplification & $C_{\mathrm{t}}$ & $\Delta \mathrm{Rn}$ & Probable amplification fail reason \\
\hline 1 & TD & $-/+$ & 32.97 & 1.97 & Partial inhibition \\
3 & PCE & - & 36.70 & 0.84 & Partial inhibition \\
& PCE & - & 33.86 & 1.83 & Partial inhibition \\
4 & TD & $-/+$ & 32.26 & 2.12 & Partial inhibition \\
& PCE & - & 33.25 & 2.05 & Partial inhibition \\
& PCE & - & 36.44 & 0.88 & Partial inhibition \\
TD & - & - & -0.004 & Invalid result \\
& EA & - & - & - & Invalid result \\
EA & - & - & - & Invalid result
\end{tabular}

Results of Quantifiler Human (QH) templates amplification and IPC analysis for DNA samples, where IPC amplification failed (-) or was weak $(-/+)$ in comparison to IPC amplification of standard dilutions of samples of known DNA quality

Fifty EA, 30 PCE and nine TD samples were analysed. Invalid result means true negative or PCR inhibition 

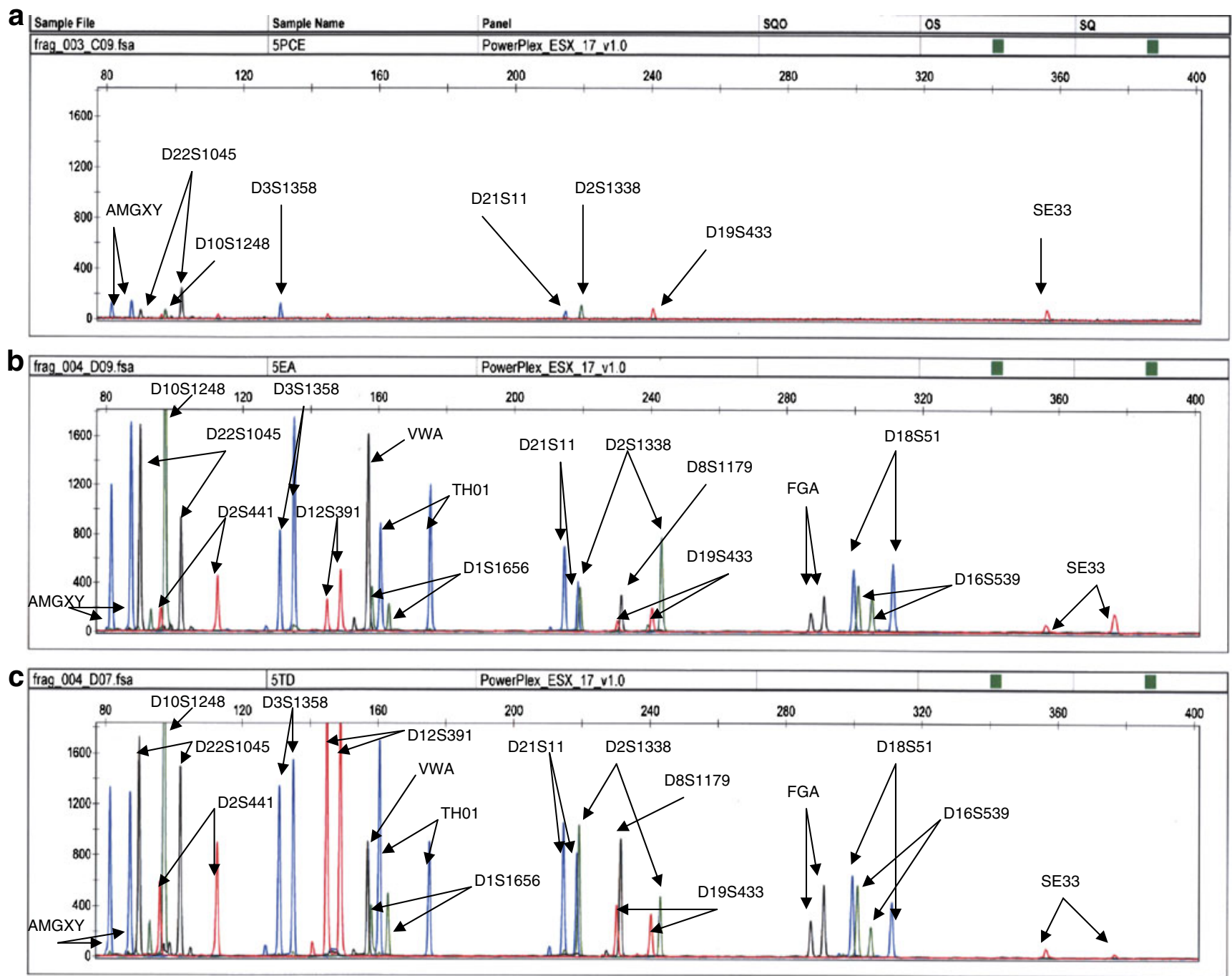

Fig. 1 PowerPlex ${ }^{\circledR}$ ESX 17 electrophoregrams obtained for DNA isolated from 62-year-old bone (B5) with PCE (a), EA (b) and TD (c) methods. Peaks with RFU above 50 were accepted

amplification (Table 2). This shows that DNA extraction from aggregates (EA) removes inhibitors much better than PCE or TD. It is possible that inhibitors do not penetrate bone crystal aggregates, and this explains why very low levels of PCR inhibition for EA method were observed. Salamon et al. [11] estimated that the PCR inhibition level in EA extracts was 5 times lower than inhibition of DNA extracts isolated from whole bone powder.

Apart from burial conditions and effects of microorganisms and inhibitors, temperature and time also had a significant influence on DNA recovery. The bone originating from remains found in winter after 3 months from death (B2) gave a higher DNA yield than the bone of the same age found in summer (B4). As expected, the fresh bone which originated from a person who died in a car accident (B8) and which was not exposed to distractive environmental conditions and the bone from a corpse found in winter soon after death (B7) gave the highest DNA recovery.
Quality of DNA

To evaluate the quality of the isolated DNA, SGM Plus and Power Plex ESX 17 kits were used. The obtained electrophoregrams were subjected to detailed analysis. It

Table 3 Effect of decalcification period on DNA concentration isolated from $500 \mathrm{mg}$ of bone powder using EA protocol

\begin{tabular}{llllll}
\hline Decalcification length & \multicolumn{5}{l}{ DNA concentration $(\mathrm{ng} / \mu \mathrm{l})$} \\
\cline { 2 - 6 } & $\mathrm{NC}$ & $\mathrm{B} 2$ & $\mathrm{~B} 5$ & \multicolumn{1}{c}{$\mathrm{B} 7$} & Average \\
\hline 1 day & 0.007 & 1.4 & 0 & 9.55 & 5.48 \\
3 days & 0 & 1.67 & 0.20 & 9.61 & 5.64 \\
5 days & 0 & 1.02 & 0.15 & 11.83 & 6.43 \\
\hline
\end{tabular}

DNA concentration was measured using Quantifiler kit (average of double measurements). Negative controls $(N C)$ were empty tubes treated as bone powder 
was found that the TD and PCE extracts gave more informative or similar profiles to the EA extracts (see supplementary data) except for the DNA obtained from the two oldest bones, B1 and B5. Using the Power Plex ESX 17 system for these two bones, EA and TD extracts gave much more informative, fuller profiles, as compared to the PCE extracts (see supplementary data). The detailed analysis of the oldest bone (B5) electrophoregrams revealed that for the EA and TD methods no loci or allelic drop-outs occurred, in contrast to the PCE method. We did not observe other artefacts like additional peaks or elevated stutters. Analysis of heterozygotes ratios showed that the lowest values observed for the TD method were $44 \%$ (D16S539) and 46\% (D2S1338 and SE33), for the EA method it was 46\% (D2S441 and D2S11338) and for the PCE method 30\% was observed for locus D22S1045 (Fig. 1). Another bone excavated from ground (B1) also gave much more informative profiles when extracted with EA and TD method in comparison to PCE; however, few allelic drop-outs were observed. This confirms that aggregates of bone crystals contain well-preserved, comparatively nondegraded DNA. On the other hand, the third exhumed bone (B9) DNA amplification was successful only when isolated with TD method (see supplementary data).

Although the number of tested bones was not high, we consider our findings remarkable. Our findings suggest that for exhumed bones, DNA extraction from aggregates (which was originally designed for degraded ancient DNA), as well as the total demineralisation protocol can be used with satisfactory results and give better amplification results than the routinely used PCE organic method. For fresh bones that have not been buried, the PCE method, as well as total demineralisation can be useful.

The good results of the TD extraction procedure may be surprising due to the poor inhibitor removal by this method, but it confirms a report that the level of inhibition does not influence significantly STR PCR success [16]. To our knowledge, no other research has been published that compares EA and TD methods with other methods of DNA extraction.

\section{Decalcification}

Salamon et al. [11] did not define the influence of a decalcification period on extraction results. In our experiments, we did not ascertain any significant effect of the length of the decalcification process on DNA recovery (Table 3 ). It seems that for well-preserved bones (B7), decalcification length does not play an important role, but degraded, older bones like B5 should be decalcified for 3 days for better results. Although decalcification is a routine procedure in many laboratories and protocols of bone DNA extraction, it has been already noted that decalcification causes a decrease in DNA recovery $[15,17,18]$ or that two-stage or prolonged decalcification can destroy DNA or reduce DNA yield [19]. On the other hand, the total demineralisation protocol assumes decalcification, but in one step with digestion, without EDTA changes [14]. This approach avoids DNA loss and seems to be the most efficient.

\section{Conclusion}

Summing up, total demineralisation is the best method for most cases of DNA extraction from bones, although it does not provide pure DNA. DNA extraction from aggregates removes inhibitors much better and is also a good method of choice when DNA must be extracted from severely degraded exhumed bones. Both of these methods give highquality DNA, good for STR loci typing, which exceeds the possibilities offered by organic extraction (PCE) for exhumed bones. One of the advantages of DNA isolation from aggregates could be the very efficient DNA contaminant elimination, which poses a serious problem especially when severely degraded bones are subjected to DNA extraction. The simple and efficient phenol-chloroform method can be successfully used for bones that have not been buried and degraded.

Conflict of interest The authors declare that they have no conflict of interest.

Open Access This article is distributed under the terms of the Creative Commons Attribution Noncommercial License which permits any noncommercial use, distribution, and reproduction in any medium, provided the original author(s) and source are credited.

\section{References}

1. Zupanic Pajnic I, Gornjak Pogorelc B, Balazic J (2010) Molecular genetic identification of skeletal remains from the Second World War Konfin I mass grave in Slovenia. Int J Legal Med 124:307-317

2. Budowle B, Bieber F, Eisenberg A (2005) Forensic aspects of mass disasters: Strategic considerations for DNA-based human identification. Leg Med 7:230-243

3. Holland MM, Cave CA, Holland CA, Bille TW (2003) Development of a quality, high throughput DNA analysis procedure for skeletal samples to assist with the identification of victims from the World Trade Center attacks. Croat Med J 44:264-272

4. Primorac D (2004) The role of DNA technology in identification of skeletal remains discovered in mass graves. Forensic Sci Int 146S: $163-164$

5. Bogdanowicz W, Allen M, Branicki W et al (2009) Genetic identification of putative remains of the famous astronomer Nicolaus Copernicus. PNAS 106:12279-12282

6. Coble MD, Loreille OM, Wadhams MJ et al (2009) Mystery solved: the identification of the two missing Romanov children using DNA analysis. PLoS ONE 4(3):e4838. doi:10.1371/journal. pone. 0004838 
7. Gill P, Ivanov PL, Kimpton C et al (1994) Identification of the remains of the Romanov family by DNA analysis. Nat Genetics 6:130-135

8. Mulligan C (2005) Isolation and analysis of DNA from archaeological, clinical, and natural history specimen. Methods Enzymol 395:87-103

9. Rohland N, Hofreiter M (2007) Ancient DNA extraction from bones and teeth. Nat Protoc 2:1756-1762

10. Nilsson M, Possnert G, Edlund H et al (2010) Analysis of the putative remains of a European patron saint-St. Birgitta. PLoS ONE 5(2):e8986. doi:10.1371/journal.pone.0008986

11. Salamon M, Tuross N, Arensburg B, Weiner S (2005) Relatively well preserved DNA is present in the crystal aggregates of fossil bones. PNAS 102:13783-13788

12. Weiner S, Price P (1986) Disaggregation of bones into crystals. Calcif Tissue Int 39:365-375

13. Hochmeister M, Budowle B (1991) Typing of DNA extracted from compact bone tissue from human remains. J Forensic Sci $36: 1649-1661$
14. Loreille O, Diegoli TM, Irwin JA et al (2007) High efficiency DNA extraction from bone by total demineralization. Forensic Sci Int Genet 1:191-195

15. Davoren J, Vanek D, Konjhodzić R et al (2007) Highly effective DNA extraction method for nuclear short tandem repeat testing of skeletal remains from mass graves. Croat Med J 48:478-485

16. Putkonen MT, Palo JU, Cano JM et al (2010) Factors affecting the STR amplification success in poorly preserved bone samples. Investig Genet 1:9

17. Rohland N, Hofreiter M (2007) Comparison and optimization of ancient DNA extraction. Biotechniques 42:343-352

18. Schwark T, Heinrich A, Preuße-Prange A, von Wurmb-Schwark N (2010) Reliable genetic identification of burnt human remains. Forensic Sci Int Genet. doi:10.1016/j.fsigen.2010. 08.008

19. Żołędziewska M, Gronkiewicz S, Dobosz T (2002) Comparison of various decalcificators in preparation of DNA from human rib bones. Anthropol Rev 65:75-80 